\title{
The Clinical Status of the Patient with Cervical Cancer Reporting in NIRCH
}

\author{
Dr. Shamima Yasmin ${ }^{1 *}$, Dr. Nasrin Ara Zaman ${ }^{2}$, Dr. Nazma Siddique ${ }^{3}$, Dr. Md Fakhrul Alam ${ }^{4}$
}

${ }^{1}$ Lt. Col., Classified Specialist, Obs and Gynae, CMH Chattogram, Associate Professor, Army Medical College, Chattogram, Bangladesh

${ }^{2}$ Brig. Gen., Professor, Advisor Specialist Obs and Gynae, CMH Jashore, Principal, Army Medical College, Jashore, Bangladesh

${ }^{3}$ Col., Classified Specialist, Obs and Gynae, CMH Chattogram, Professor, Army Medical College, Chattogram, Bangladesh

${ }^{4}$ Lt. Col., BSP, MPH Commanding Officer, 11 Field Ambulance, Savar Cantonment, Bangladesh

DOI: $10.36347 /$ sjams.2020.v08i05.043

| Received: 16.05.2020 | Accepted: 23.05.2020 | Published: 30.05.2020

*Corresponding author: Dr. Shamima Yasmin

Abstract

Original Research Article

Objective: In this study our main goal is to evaluate the clinical statusof the patient with cervical cancer reporting in NIRCH. Method: this retrospective study was done at NICRH, Dhaka from June 12017 to June 12019 . A total of 384 patients who diagnosed as cervical cancer were included in the study. Results: during the study, among 384 patients, 214 were illiterate. Followed by 92 patients passed primary, 70 patients were passed secondary and only 8 people passed college. 222 patients had low economic status. Followed by 73 had multiple sex partner, 251 had poor personal hygiene, 176 used OCP. 30\% had post-menopausal bleeding. Followed by $23.70 \%$ had intermenstrual bleeding, $14.06 \%$ had post coital bleeding, $19.01 \%$ had Excessive whitish $\mathrm{p} / \mathrm{v}$ discharge, $14.32 \%$ had foul smelling discharge. Conclusion: In most cases of cervical cancer in early stage is symptomless. Here I give emphasis on important risk factors and characteristics of cervical cancer patients. Poor resource countries like Bangladesh, it will help by screening to detect early invasive carcinoma and can help plan of management and thereby to attain good prognosis.

Keywords: Clinical profile, cervix, cervical cancer.

Copyright @ 2020: This is an open-access article distributed under the terms of the Creative Commons Attribution license which permits unrestricted use, distribution, and reproduction in any medium for non-commercial use (NonCommercial, or CC-BY-NC) provided the original author and source are credited.

\section{INTRODUCTION}

Cancer of the cervix is the most common genital tract malignancy in the female and is a major public health problem in the developing countries [1]. Worldwide, about half a million new cases are seen each year, with majority coming from the developing nations. In India, more than 1.2 lac new cases of cancer of cervix uteri occurred in the year 2012 with agespecific incidence rate of 22 per 100,000 [2]. It is estimated that cervical cancer will occur in approximately 1 in 53 Indian women during their lifetime compared with 1 in 100 women in more developed regions of the world.

The exact cause of cervical cancer remains unknown. However, it is now well recognized that cervical cancer is more common among women living in poor conditions, with low-income levels and lack of education. There are abundant studies on risk factors related with cervical cancer. In addition to human papillomavirus, there are various risk factors associated with cervical cancer such as early age at marriage, early age at first sexual intercourse, a greater number of sexual partners, high parity, and smoking $[3,4]$.

In this study our main goal is to evaluate the clinical status of the patient with cervical cancer reporting in NIRCH.

\section{OBJECTIVE}

\section{General Objective}

To evaluate the clinical status of the patient with cervical cancer reporting in $\mathrm{NIRCH}$

\section{Specific Objective}

- To detect educational level of the patients.

- To identify risk factors related to patient. 


\section{Methodology}

\begin{tabular}{|l|l|}
\hline Type of study & Retrospective study \\
\hline Place of study & NICRH,Dhaka \\
\hline Study period & June 1 2017 to June 1 2019 \\
\hline Study population & Total no of sample was 384 who were diagnosed as cervical cancer \\
\hline Sampling technique & Purposive \\
\hline
\end{tabular}

\section{METHOD}

It is a record based retrospective study and was carried out to evaluate the medical records of women with cervical cancer treated for surgery or with radiotherapy and chemotherapy. The data on sociodemographic factors and clinical profile of 384 cervical cancer patient were recorded in data sheet.

\section{Statistical Analysis}

First data were edited to the validity and consistency of the data. After proper verification data were coded and entered into computer by using SPSS software programs. Descriptive analysis was done by percentage, mean and standard deviation. Association was observed by appropriate statistical test at $95 \%$ confidence interval eg. odds ratio, Chi-squiare, t-test.

\section{RESULTS}

In Table-1 shows age distributions of the patients where most of the patients belong to 45-54 years $(32.03 \%)$ age group. The following table is given below in detail:

Table-1: Age distribution

\begin{tabular}{|l|l|l|}
\hline Age & No. of Patients & \% of Patients \\
\hline$<35$ & 8 & 2.08 \\
\hline $35-44$ & 67 & 17.45 \\
\hline $45-54$ & 123 & 32.03 \\
\hline $55-64$ & 112 & 29.17 \\
\hline $65-74$ & 61 & 15.88 \\
\hline 75 and above & 13 & 3.38 \\
\hline
\end{tabular}

In Figure-1 shows marital status of the patients where $91.14 \%$ patients were married and $8.86 \%$ patients where unmarried. The following figure is given below in detail:

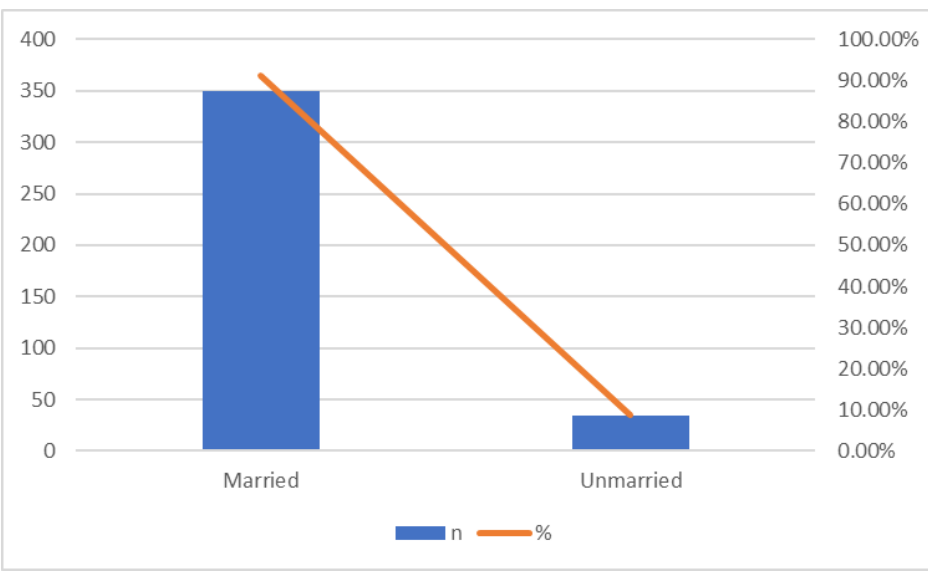

Fig-1: Marital status of the patients

In Table-2 shows educational level of the patients where among 384 patients, 214 were illiterate. Followed by 92 patients passed primary, 70 patients were passed secondary and only 8 people passed college. The following table is given below in detail:

Table-2: Educational level of the patients

\begin{tabular}{|l|l|}
\hline Stage & No. of Patients \\
\hline Illiterate & 214 \\
\hline Primary & 92 \\
\hline Secondary & 70 \\
\hline College and above & 8 \\
\hline
\end{tabular}


In Table-3 shows risk factors related to patient where out of 384 patients, 222 patients had low economic status. Followed by 73 had multiple sex partner, 251 had poor personal hygiene, 176 used OCP. The following table is given below in detail":

Table-3: Risk factors related to patient

\begin{tabular}{|l|l|l|}
\hline Risk factors & No. of patient & \% of patient \\
\hline Age of marriage<18 yrs & 186 & $48.43 \%$ \\
\hline Ground multipara & 311 & $80.99 \%$ \\
\hline Low socioeconomic conditions & 222 & $57.81 \%$ \\
\hline Multiple sex partner & 73 & $19.01 \%$ \\
\hline OCP uses & 176 & $45.83 \%$ \\
\hline High risk male partner & 70 & $18.23 \%$ \\
\hline Poor personal hygiene & 251 & $65.36 \%$ \\
\hline
\end{tabular}

In Table-4 shows distribution of the patients according to symptomatology where $30 \%$ had postmenopausal bleeding. Followed by $23.70 \%$ had intermenstrual bleeding, $14.06 \%$ had post coital bleeding, $19.01 \%$ had Excessive whitish p/v discharge, $14.32 \%$ had foul smelling discharge. The following table is given below in detail:

Table-4: Distribution of the patients according to symptomatology

\begin{tabular}{|l|l|l|}
\hline Symptoms & No. of cases & Percentage \\
\hline Post coital bleeding & 54 & 14.06 \\
\hline Intermenstrual bleeding & 91 & 23.70 \\
\hline Post-menopausal bleeding & 119 & 30.99 \\
\hline Excessive whitish p/v discharge & 73 & 19.01 \\
\hline Foul smelling discharge & 55 & 14.32 \\
\hline Other Malignant featured & 03 & 0.78 \\
\hline Backache & 05 & 1.30 \\
\hline Urinary complains & 04 & 1.04 \\
\hline
\end{tabular}

In Table-5 shows clinical profile of cervical cancer patients where most of the patients in stage-II, $47.92 \%$ followed by $19.80 \%$ in stage-I, $30.99 \%$ in stage
III and only $1.30 \%$ in stage-IV. The following table is given below in detail:

Table-5: Clinical profile of cervical cancer patients

\begin{tabular}{|l|l|l|}
\hline Clinical factors: Stage & No. of patients & Percentage \\
\hline I & 76 & 19.80 \\
\hline II & 184 & 47.92 \\
\hline III & 119 & 30.99 \\
\hline IV & 5 & 1.30 \\
\hline Histology Squamous & 336 & 87.50 \\
\hline Acleuo Carcinoma & 48 & 12.5 \\
\hline Performance status (score) normal, asymptomatic & 274 & 71.35 \\
\hline Symptomatic, ambulatory (1) & 60 & 15.62 \\
\hline Symptomatic, united work (2) & 8 & 2.08 \\
\hline Symptomatic, in bed ( $\geq 3)$ & 5 & 1.30 \\
\hline Unknown & 3 & 0.78 \\
\hline
\end{tabular}

In Figure- 2 shows comorbid condition of the patients where 55 patients had diabetes, 15 patients had hypertension, patients had heart diseases. The following figure is given below in detail: 


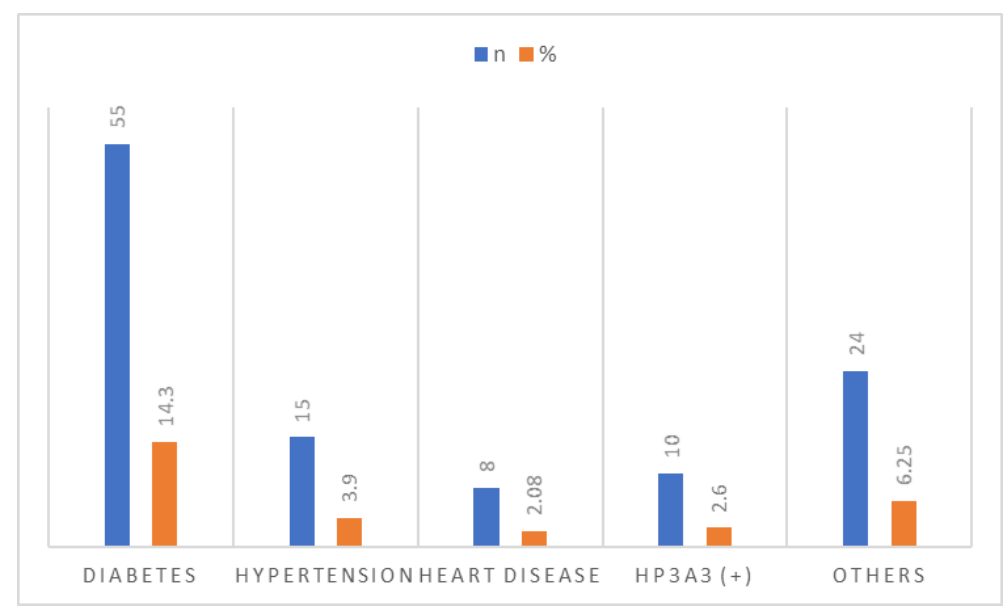

Fig-2: Comorbid condition of the patients

In Table- 6 shows relation of age staging of disease where in stage-IV patients mean age was 58.6 years, followed by in stage-I it was 49 years, in stage II mean age was 54 years, in stage-III it was 56 . The following table is given below in detail:

Table-6: Relation of age staging of disease

\begin{tabular}{|l|l|}
\hline Stage & Median Age (year) \\
\hline I & 49 \\
\hline II & 54 \\
\hline III & 56 \\
\hline IV & 58.5 \\
\hline All stages & 54 \\
\hline
\end{tabular}

In Table-7 shows association between staging and education where in stage-I, 50 patients were illiterate, 16 passed primary, 10 passed secondary level. The following table is given below in detail:

Table-7: Association between staging and education

\begin{tabular}{|l|l|l|l|l|}
\hline Stage & Illiterate & Primary & Secondary & Total \\
\hline I & 50 & 16 & 10 & 76 \\
\hline II & 63 & 89 & 32 & 184 \\
\hline III & 55 & 43 & 10 & 119 \\
\hline IV & 3 & 2 & - & 5 \\
\hline All stages & 182 & 150 & 52 & 384 \\
\hline
\end{tabular}

\section{DISCUSSION}

In our study most of the patients belong to 45 54 years $(32.03 \%)$ age group. In one study it was found that, the median age of cervical cancer patients in their study [5]. This older age indicates a relative lack of awareness and non-availability of screening facilities for about cervical cancer in country [6].

In one report said that, $54 \%$ of patients were illiterate, whereas only $4 \%$ have had qualification of college and above [7]. Which is quite similar to our study where 214 were illiterate. Followed by 92 patients passed primary, 70 patients were passed secondary and only 8 people passed college. This finding is in consonance with many studies which has found illiteracy as a risk factor for cervical cancer [7, 8].

Similarly, lack of education has also been linked early marriage and high parity which are also considered as risk factors for cervical cancer, thus improving theeducational status of women in our country is an essential component of holistic approach for cervical cancer control. In our study, out of 384 patients, 222 patients had low economic status. Followed by 73 had multiple sex partner, 251 had poor personal hygiene, 176 used OCP. Also, we found that, $91.14 \%$ patients were married and $8.86 \%$ patients where unmarried. Which was supported by one study where they found that $75.42 \%$ patients were currently married, which is higher than $62.4 \%$ [9].

In one article reported that, $13 \%$ cases had early stage disease (Stage I) and more than $50 \%$ patients had presented with advanced stage disease (Stage III and IV) [10]. Whereas in our study we noted that, most of the patients in stage-II, $47.92 \%$ followed by $19.80 \%$ in stage-I, $30.99 \%$ in stage III and only $1.30 \%$ in stageIV. 


\section{CONCLUSION}

In Bangladesh cervical cancer load is high and one of the leading cause of death among women where screening programs are not well established. WHO estimates death in adult female is $35 \%$ due to cervical cancer. This study is the first step planning for screening and control measures. Mass campaign can help in creating awareness on the risk factors and prevention of cervical cancer. It is the only gynaecological cancer for which screening test is present and can be cured, ultimately the prognosis is good if diagnosed earlier. Though scarcity of screening program it is most wanted preventive measures should be given more importance while giving health education.

\section{REFERENCE}

1. Awodele O, Adeyomoye AA, Awodele DF, Kwashi V, Awodele IO, Dolapo DC. A study on cervical cancer screening amongst nurses in Lagos University Teaching Hospital, Lagos, Nigeria. Journal of Cancer Education. 2011 Sep 1;26(3):497-504.

2. Ferlay J, Soerjomataram I, Ervik M, Dikshit R, Eser S, Mathers C, Rebelo M, Parkin DM, Forman D, Bray F. GLOBOCAN 2012 v1. 0, Cancer incidence and mortality worldwide: IARC CancerBase No. 11. International Agency for Research on Cancer, Lyon, France. 2013. globocan. iarc. fr. 2015.

3. Institute for Health Metrics and Evaluation. The Challenge Ahead: Progress in Breast and Cervical Cancer. Institute of Health Metrics and Evaluation. 2011. [Last accessed on 2013 Jan 21]. Available from:

Http://www.healthmetricsandevaluation.org/public ations/policyreport/challenge-ahead-progress-andsetbacks-breastand-cervical-cancer.
4. International Collaboration of Epidemiological Studies of Cervical Cancer. Comparison of risk factors for invasive squamous cell carcinoma and adenocarcinoma of the cervix: collaborative reanalysis of individual data on 8,097 women with squamous cell carcinoma and 1,374 women with adenocarcinoma from 12 epidemiological studies. International journal of cancer. 2007 Feb 15;120(4):885-91.

5. Franceschi S, Plummer M, Clifford G, De Sanjose S, Bosch X, Herrero R, Munoz N, Vaccarella S. Differences in the risk of cervical cancer and human papillomavirus infection by education level. British journal of cancer. 2009 Sep;101(5):865-70.

6. Green J, De Gonzalez AB, Sweetland S, Beral V, Chilvers C, Crossley B, Deacon J, Hermon C, Jha P, Mant D, Peto J. Risk factors for adenocarcinoma and squamous cell carcinoma of the cervix in women aged 20-44 years: the UK National Case-Control Study of Cervical Cancer. British journal of cancer. 2003 Dec;89(11):207886.

7. Rajkumar T, Franceschi S, Vaccarella S, Gajalakshmi V, Sharmila A, Snijders PJ, Munoz N, Meijer CJ, Herrero R. Role of paan chewing and dietary habits in cervical carcinoma in Chennai, India. British journal of cancer. 2003 May;88(9):1388-93

8. Balasubramaniam G, Sushama S, Rasika B, Mahantshetty U. Hospital-based study of endometrial cancer survival in Mumbai, India. Asian Pac J Cancer Prev. 2013;14:977-80.

9. Balasubramaniam G, Talole S, Mahantshetty U, Saoba S, Shrivastava S. Prostate cancer: A hospital-based survival study from Mumbai, India. Asian Pac J Cancer Prev. 2013;14:2595-8.

10. Ganesh B, Swaminathan R, Mathew A, Sankaranarayanan R, Hakama M. Loss-adjusted hospital and population-based survival of cancer patients. IARC Sci Publ. 2011;162:15-21. 